\title{
Exploring a Practical Pathway toward Democracy in China
}

\author{
Jiahong $\mathrm{He}^{1}$ \\ ${ }^{1}$ School of Law, Renmin University of China, Beijing, China \\ Correspondence: Jiahong He, School of Law, Renmin University of China, Beijing, China.
}

Received: April 30, 2020

doi:10.11114/ijsss.v8i4.4864

\author{
Accepted: May 13, 2020 \\ Available online: May 20, 2020 \\ URL: https://doi.org/10.11114/ijsss.v8i4.4864
}

\begin{abstract}
The current democratic system in the People's Republic of China (PRC) is based on the political consultation and the people's congress. In this system of indirect democracy, the key is to ensure that those in power are representing the people's interests. Over the last thirty years, China has been exploring the pathway toward democracy, but a long road lies ahead. Currently, China needs to take substantial practical measures to guarantee people's democratic rights, including the right to know, the right to speak, and the right to vote.
\end{abstract}

Keywords: China, democracy, right to know, right to speak, right to vote

\section{Introduction}

Generally speaking, democracy with the rule of law is the developing trend in the world, and shuld be the goal for China, too. Over the last forty years, China has achieved a positive economic trajectory, and now, Chinese people's lives have improved. With this change, a growing need for democracy and rule of law has emerged. While the Chinese government has made some significant achievements based on their experiences and the lessons acquired while exploring a pathway toward democracy over the past seventy years, the ultimate goal is still a long way from the present position.

When considering China's history, cultural traditions, and social systems, it seems that the Chinese political system should follow a democratic model that has the people's congresse at its core, supported by a multi-party cooperation and political consultation under the leadership of the Communist Party of China (CPC). In the PRC's Constitution, it clearly stipulates that the CPC's leadership is the basic feature of China's political system, which is a centralized democracy. Therefore, China cannot "import" the American model of democracy. ${ }^{i}$

China's current democratic system is considered an indirect democracy. According to relevant provisions in the Constitution, all powers of the People's Republic belong to the people. The people's congress is the fundamental political system of China, and derives its authority from the people. The people's congress is elected by and responsible for the people, so they are subject to the people's supervision. (Yu Keping, 2018: pp.15-17) Therefore, the power of the state belongs to the people and can only be exercised by the people's congress or the people directly.

Under this indirect democratic model, there are two paths to ensure that the people are the masters of their country. First, in democratic elections, the pre-event guarantee allows representatives, who are trusted by the people, to discuss state affairs. Second, the post-event guarantee entails democratic supervision that allows people to examine whether representatives' decisions are in the people's interests. Accordingly, China should take substantial practical measures to guarantee people's rights to promote democracy. In other words, China should explore a practical pathway to achieve democracy based on people's rights: to know, speak, and vote.

\section{Protecting People's Right to Know}

Citizens of a country, as well as any members of any society, deserve the right to know about situations and gain access to relevant information. Depending on the nature of information, the right to know may fall into one of three categories. The first category is the right to know governance information, such as state affairs, governmental decisions, and officials' activities. The second is the right to know social information, including the state of social development and material issues. For example, the public has the right to be informed about material events or accidents. The third is the right to know citizens' personal information. In other words, a citizen has the right to know their biological parents, birth date, and time of birth, as well as other personal data. In a democracy, citizens' right to know falls under the first category, the right to know governance information. In China, all citizens enjoy this right. However, since this 
information is often under government control and kept secret, citizens' right to know can also be interpreted as having free access to this information.

In a democratic country, citizens are the masters and possess the right to access governance information. In the case of direct democracy, citizens' right to know goes without saying. Once people are informed of a situation, they can decide or express their expectations on a certain issue. In the case of indirect democracy, however, people's right to know is particularly important because all state affairs are decided by the political elite on behalf of the people. Therefore, citizens must know what is happening or they are merely masters of the country in name only. For this reason, the people's right to know is a watershed for both democracies and despotisms. History has demonstrated that dictators have often practiced obscurantism in an attempt to limit or even deprive people of their right to know.

In the Western Zhou Dynasty over two thousand years ago, an obstinate, autocratic political culture had developed after a long history of feudalism, and one of its features was denying people's right to know. In a summary of the Criminal Law, the rulers explained, "When the law is unknown, its deterrence is extremely powerful". (Zhang Guohua, 1982: p.37) In other words, deterrence has a powerful effect when the masses do not understand the specific provisions of the Criminal Law, what constitutes a crime, or what the punishment entails.

In the Zheng State, Zichan launched a reform to increase the state's power. One of these actions involved building a copper tripod with the Criminal Law engraved on it to reveal its contents to the public. Some aristocrats opposed his move, "the deceased king ruled the state with resolutions rather than by the Criminal Law [...] if the people know the law, they will have no fears". In other words, if people know the specific rules, they will no longer venerate and be in awe of His Majesty. Later on, other states followed, but they met with resistance. For instance, a Criminal Law tripod was also established in the Jin State, and it included an engraving of the statute law. Although it was only used at the imperial court and "never disclosed to the public," some aristocrats were still opposed. According to Confucius, "The Jin State perished, because it lost its law." (Zhang Jinfan, 1985: p.60) Also, Confucius had a famous saying: "We may have the people obey the order of the king but do not tell them why", which means that people do not need to know what is going on. They obey the king's orders either because they are foolish or the policies are incomprehensible. ${ }^{\text {ii }}$ This kind of obscurant was needed in an autocratic government and preferred by the feudalist kings. From the rulers' perspective, blind worship was ideal, and it demonstrated proof of their excellent leadership. While it was terrific for them to have millions submit to their authority without asking why, obscurantism is the natural enemy of democracy. Society must dismiss obscurantism in pursuit of democracy instead.

In contemporary China, how is the people's right to know protected? According to the Election Law, deputies of the county-level and lower-level congresses are directly elected by the electorates, while the deputies of other levels are indirectly elected. Specifically, deputies of the municipal people's congresses are elected by the counties (i.e., districts), while deputies of the provinces are elected by the cities, and the National People's Comgress (NPC) deputies are elected by the provinces. Due to this three-tier election ladder, the bond between NPC deputies and the masses (i.e., the electorates at the grassroots level) is incredibly weak. Except for a few leading officials and social celebrities, the people have limited knowledge about NPC deputies. Since they cannot come to know these deputies through direct elections, they are unable to ensure that they are voting for trustworthy deputies. Therefore, to begin improving democracy in China, the people should have the right to know more information about NPC deputies, which can be divided into four components: (1) personal information, (2) family information, (3) information about the NPC's decision-making process, and (4) background information regarding the decisions that were made at the NPC.

The first component concerns NPC deputies' personal information, which includes details about what kind of person they are (e.g., their name, gender, age, nationality, occupation, title, education, and professional experience). On the NPC portal, the names of the deputies are listed from all the provinces, autonomous regions, and municipalities, and it includes their gender and nationality. However, additional details that people should know, like a biography that includes their occupation and title, are unavailable. Although the Internet and big data can be utilized via search engines to discover the personal information of many deputies, this information may be incomplete or inaccurate. Instead, the NPC should be the single disclosure source for this information to guarantee the people's right to know.

The second component involves sharing NPC deputies' family information, from family properties to family members (e.g., spouses and children). Since these pieces of information are key to understanding someone, the NPC should disclose deputies' family information to the public in the same way that they divulge personal matters reported by officials. This is a crucial step for progressing Chinese democracy to the next level.

The third component involves information about the NPC's decision-making process. In accordance with Articles 62 and 63 of the Constitution, the NPC and its Standing Committee have three primary responsibilities: (1) to enact, amend, and interpret statutes and supervise the enforcement thereof; (2) to elect key leaders; and (3) to examine and approve decisions concerning major state affairs. ${ }^{\text {iii }}$ Currently, Chinese citizens may know about the NPC's final decisions, but 
they are not well-informed about the decision-making process. Among other media outlets, television and newspaper reporters may cover meetings of the NPC and its Standing Committee, but the decision-making process happens behind closed doors and remains a mystery to the public. Many questions concern public interests: What law is being composed? Who will take office? How is the country's money spent? As masters of the country, people have the right to know not only what decisions are made but how they are made, including their basis and rationale. While public representatives are not permitted to sit in on NPC and Standing Committee sessions, the decision-making process may be revealed to the public through visual methods (e.g., text, pictures, television, internet) and/or audio forms (e.g., radio), so the people's right to know can be met.

The fourth component of this information retrieval process would concern the background of the decisions that are made at the NPC. This would cover the drafting of laws and amendments, the nominees for state leaders, and notes regarding major decisions. Of these facets, the nominees for state leaders are likely the item that most interests the masses. As in many countries, the election of the topmost leaders is at the core of the democratic design, so disclosing this information would be significant progress toward attaining democracy in China. Although state leader appointments are not directly decided by the people currently, they should still know how the decisions are made. In other words, the people may not have the right to vote, but they have the right to know. This is an essential requirement for political transparency, and it can be a catalyst for advancing political civilization. For example, in a transparent political environment, it is more likely that candidates will act and compete more civilly and on equal footing. Also, policymakers will have to act impartially and selflessly to convince the public by reasoning, which may stimulate a positive change in the officialdom and bring China's democracy to the next level.

The people's right to know cannot be accomplished in a single stroke, but it can be introduced in phases that begin with the easiest task and proceed to the most difficult. Under the leadership of the CPC Central Committee, the NPC's Standing Committee may implement the four components of the information disclosure described above through a fixed timetable, where they are introduced one-by-one. The author suggests that the first component is the easiest and should be disclosed within one year. There will be a strong resistance against disclosing the second component, so an information disclosure process that is based on random choice should be piloted during the $13^{\text {th }}$ NPC's term of office. So, while the NPC and the Chinese People's Political Consultative Conference (CPPCC) are holding annual sessions, $10 \%$ of the NPC deputies would be randomly selected for family property information disclosure first, and then, the family member information disclosure would follow. Afterward, all NPC deputies would adhere to family information disclosure by the $14^{\text {th }}$ NPC. The information disclosure of third component could be piloted at the $13^{\text {th }}$ NPC's term of office. Some sessions of the Standing Committee could be livestreamed or broadcasted live on television, and then, the rollout would be complete by the $14^{\text {th }}$ NPC's term of office. The fourth component is the most challenging, as the information disclosure could be piloted when the $14^{\text {th }}$ NPC's expires, and then, it could be rolled out when the $15^{\text {th }}$ NPC expires. According to this timetable, it would take approximately ten years to protect the people's right to know that was proposed at the CPC's $17^{\text {th }}$ National Congress.

\section{Protecting People's Right to Speak}

Humans are social creatures with many thoughts and ideas, which they feel the need to exchange in almost every aspect of their social lives, from obtaining food, mating, giving birth, and raising children to experiencing collective amusement. Since people feel compelled to shared ideas, they are also born with a need to speak. Language is a product of this need, so it has evolved as this need has expanded. In early times, humans were free to express themselves, but then, the freedom of speech became subject to increasing constraints and restrictions as social governance was tightened and state power grew stronger. When the king, which ruled over the state, became powerful enough to exercise autocracy or even dictatorship, the people's freedom of speech became restricted and even cruelly denied.

Throughout the 5,000 years of Chinese civilization, the ruler of each dynasty controlled freedom of speech for the most part. There were periods of despotism and tyranny, but the majority of people possessed freedom of speech. This can be observed in many classic writings that were passed down from the Pre-Qin Period: The Book of Songs, The Book of Changes, The Book of History, The Zuo's Commentary, Lao Tzu, The Analects, Meng-tzu, and Mong-tzu, the poetries of the Tang Dynasty and the Song Dynasty, the operas of the Yuan Dynasty, and the novels of the Ming Dynasty and Qing Dynasty. One radical change that occurred was when the First Emperor of Qin Dynasty unified the country in 221 B.C..

During the Spring and Autumn Period and the Warring States Period from 770 to 221 B.C., social changes and divided political power had contributed to active thoughts and the prevalence of a wide variety of theories. The kings were trying their best to attract and retain talented people, while society's thinkers traveled and gave lectures. While some acted as state policy advisors, others wrote books and established theories. Once a decree was enacted, people could discuss, debate, and criticize it. During this period of Chinese history, a multitude of ideas was budding and thriving, and the freedom of speech was enjoyed to the fullest. Sima Qian wrote: 
All kings were vying with each other to attract scholars with good treatment [...] Once an order came out, all scholars commented on it. When they were on the royal court, they had dissents but kept their mouth shut; when they were on the street, they commented on it openly (Records of the Historian: The Biography of the First Emperor of Qin).

After unifying the country by force, the First Emperor of Qin exercised a centralized autocracy, so he could not allow all schools of thoughts to exist or tolerate any act of disparagement against the present system by extolling the past. So, he resorted to cultural despotism and obscurantism. In 213 B.C., he adopted Prime Minister Li Si's advice and issued an order to burn The Book of Songs, The Book of History, and other classics that the people had collected. The following year, he buried approximately 460 scholars in Xianyang for defaming the royal court. (Zhang Guohua, 1982: pp.142-143) He desired to ban any thought that could potentially threaten his rule. Moreover, he was determined to wipe out the carriers of these harmful thoughts, including both the books and their carriers. This is an example of establishing radical mind control at the root!

This way of rule, which entailed the suppression of dissent and imposing obscurantism to restrict thoughts, influenced the ruling policies of the generations with feudalist rulers that followed. For example, the Qianlong Emperor of the Qing Dynasty was a fan of culture, so he ordered the creation of The Complete Library in Four Sections (The Siku Quanshu). Meanwhile, however, he imprisoned some scholars for producing (allegedly) inappropriate writings and ordered the elimination of forbidden books. Since Qianlong did not specify which books were forbidden or how to eliminate them, some officials had to decipher his intention by using their talents and/or discretion. Hai Cheng, Governor of Jiangxi Province, had an idea that embarrassed Qianlong: "All scholars in the country must submit any book they have written to local officials for review, or else, they will be punished for reactionary speech in private." (Yang Nianqun, 2013, pp.38-39)

Of course, some open-minded emperors did not want to maintain people's ignorance. Immediately after its inception, the Han Dynasty inherited the Qin Dynasty's cruel, strict Law on Libel and Rumormongering, where any person who began a rumor or discussed government policies by either complaining or discrediting them would be sentenced to death. Then, Liu Heng, Emperor Wen of the Han Dynasty, abolished this law in his second year after being enthroned. This provided the freedom of speech to officials and the general public. (Zhang Guohua, 1982: p.162) Li Shimin, Emperor Taizong of the Tang Dynasty, was eager to take advice and content to hear negative comments concerning his faults:

I am open to advice and this is good for our country [...] An open-minded emperor reflects on his faults and becomes a better man every day, while a narrow-minded emperor tries to cover up his faults and stays foolish forever." (Zhang Guohua, 1982: p.248)

These wise rulers offered the freedom of speech to both officials and the people to consolidate their power rather than allowing the people to rule the nation.

The right to speak describes a citizen's right to freely express their viewpoints and opinions. The right to speak is part of freedom of speech in that it is a right that citizens may freely exercise. Since speech and the press are the primary format and carriers for citizens to express their views, the freedom of speech and freedom of the press are the primary elements that consist of the right to speak. In any democratic country, the right to speak is one of a citizen's basic rights. As masters of the country, people have the right to comment on state affairs.

The right to speak means defending citizens' freedom to voice their objections and criticisms. To applaud merits and virtues is also a form of speech, but this does not need protection since it does not risk being controlled or suppressed. According to Article 41 of the Constitution:

Citizens of the People's Republic of China have the right to criticize and make suggestions to any state organs or functionary; citizens have the right to make known to relevant state organs complaints and charges against, or exposures of, violation of the law or dereliction of duty by any state organ or functionary; but fabrication or distortion of facts with the intention of libel or frame-up is prohibited. In case of complaints, charges or exposures made by citizens, the state organ concerned must deal with them in a responsible manner after ascertaining the facts. No one may suppress such complaints, charges and exposures, or retaliate against the citizens making them. ${ }^{\text {iv }}$

Citizens' right to speak is protected by the Constitution, so their right and freedom to discuss or criticize any state policy or governmental decision is also subject to the law's restrictions and constraints. Article 51 of the Constitution says:

The exercise by citizens of the People's Republic of China of their freedoms and rights may not infringe upon the interests of the state, of society and of the collective, or upon the lawful freedoms and rights of other citizens. ${ }^{v}$

While freedom of speech is explicitly specified in the Constitution, a gap exists between the law's language and reality. Article 35 of the Constitution is significantly general, while Article 51 consists of abstract as well as general 
constraints. Many issues may have a bearing on exercising the right to speak in reality: How can we judge whether a citizen's speech has infringed upon the interests of the state, society, and/or the collective? Due to the absence of specific rules, some public officials may scrutinize and restrict citizens' right to speak in accordance with the internal policies or rules of the agency or the organization. Some public officials would rather move toward the left-wing than the right-wing to tighten these policies or rules of enforcement, and as a result, citizens' right to speak is subject to inappropriate, undue suppression. In this context, normal speeches may be dubbed nonsense and justified words may be tagged as "taboo" or "sensitive." Moreover, when a citizen's right to speak is hampered or infringed upon, they scarcely have access to a legal remedy.

The government primarily limits the right to speak through two means: (1) prior reviews and limitations; and (2) accountability and penalty afterwards. Presently, China's limitations concerning the right to speak are primarily performed via prior administrative and departmental reviews, which is a practice that helps prevent the dissemination of malicious comments and reduces the harm they cause. However, it may infringe on the people's freedom of speech, especifically the practice of prior review with the internal regulations of a political nature. The means and approaches by which citizens may exercise their right to speak are diversified. Based on the various means and ranges of speech, the right to speak may be divided into four levels, which can be utilized, in turn, as four steps toward improving citizens' right to speak.

The first level of the right to speak is the freedom of speech through governmental bodies. Chinese citizens may express their thoughts through governmental bodies, such as the NPC, the CPPCC, the State Council (including its ministries and commissions), the CPC, democratic parties, labor unions, the Women's Federation, and the Communist Youth League. Public complaints, proposals, and public hearings are important ways for citizens to express their opinions. Published in 1996, the Administrative Penalty Law specifies the procedures for administrative hearings. Published in 2000, the Legislation Law states that the introduction of important laws must be reviewed through hearing procedures, and in 2005, the State Council issued an administrative decree that the government's formulation of important policies at all levels must undergo these hearing procedures. (Mo Yuchuan, 2015: p.198) Furthermore, activities organized by local governments, such as "democratic talks" and public comments concerning government actions, are also a means for citizens to express their thoughts. (Yu Keping, 2018: p.115)

The second level of the right to speak is freedom of speech through civil group activities. Society consists of various units, including enterprises, public institutions, nongovernmental organizations, trade associations, and social groups. Citizens often express their personal opinions in events that are organized by these groups, such as seminar speeches, addresses at mass meetings, school lectures, training classes, trade talks, company meetings, and family gatherings. These speeches are considered public and should be protected under a citizen's right to speak.

The third level of the right to speak is freedom of speech through traditional mass media, as people need to be able to publicly communicate information. With recent developments in science and technology, the media (on which this communication depends) continues to grow. Traditional mass media that is used for communication includes books, newspapers, magazines, radio, television (e.g., drama and films), and literary works. Aside from portraying people's thoughts and opinions, these media outlets also allow people to communicate their expressions to a larger audience. For example, the largest printed newspapers and magazines, as well as remotely transmitted radio and television programs, can amplify people's thoughts and opinions to tens of millions of people. Therefore, an important component of the right to speak is represented by citizens' freedom of speech to utilize the mass media.

The fourth level of the right to speak is freedom of speech concerning the new mass media, which primarily refers to information communication channels that have emerged from new technology, such as computers, mobile phones, and the Internet (e.g., micro-blogs and WeChat platforms). This is also called, "WeMedia," as it consists of media that has been spontaneously and independently created by citizens rather than being controlled by officials or commercial media organizations. New mass media has features, like quickness, universality, and interactivity, which not only provide citizens with more diversified channels and larger spaces to exercise the right to speak but also present new challenges to the government concerning its control of speech and the press. Society's democratic patterns and ideas may undergo tremendous changes as we enter into the so-called, "electronic democracy"vi era, especially with the introduction of big data, artificial intelligence, and blockchains in mass media.

Currently, in China, we need to strengthen the protection of the right to speak. First, we need to improve the relevant legal systems by formulating special laws, such as the press and publication laws. Second, we need to specify the principle of safeguarding the right to speak with the exception of limiting citizens' freedom of speech and the legal standards for limiting the right to speak. If necessary, we need to establish specified rules and standards based on judicial interpretations and precedents. Third, the focus of limiting freedom of speech should shift from administrative 
review to subsequent judicial review. We should make these improvements in the proper order by following the four levels of the right to speak in an attempt to achieve this goal over the course of ten years.

\section{Protecting People's Right to Vote}

\subsection{Voting is the Primary Method to Perform Democratic Elections}

In a nation's government, people typically allow a few to decide the affairs of the entire state. The best method for ensuring that these people represent the public's interests in their decision-making is for the public to decide who will represent them. Therefore, the election of state leaders by the people is the basic form of democracy. In fact, elections are universal in human society, and the election of officials is an indispensable public affair, whether it occurs in ancient or modern times, in China or abroad.

In Chinese, the original meaning of the word, "election," is "selecting and recommending sages," especially concerning the selection of officials. According to historical records, since the Sui Dynasty, "officials have been appointed by the Ministry of Personnel, which is in charge of the selection ${ }^{\text {vii }}$ and performance evaluation of officials." "viii In ancient China, there were many types of official elections. According to the History of the Ming Dynasty-Officials Records I, "Regarding elections, every year there were general elections, urgent elections, distant elections, and teachers elections by annual tribute, in addition to choosing and provincial graduates elections. ${ }^{\text {ix }}$ As a political science term, elections refer to the "act of citizens (electors) electing certain public officials in accordance with the legal form." (Pi Chunxie, 1986: pp. 512-513) Although the election may be decided by a show of hands, acclamation, consultation, or drawing lots, for example, in today's world, the election of people's representatives or heads of government is generally completed through a referendum. Therefore, unless it is restricted by special terms, the word, "election," refers to voting.

\section{1) The Universality of Elections}

There are many elections in the United States, and as a federal country, the election of officials can be divided into four levels: federal, state, county, and city. Elections at the federal level, for example, include the Presidential, Senate, and House of Representatives elections. Other elections in the United States include that of governors, senators, and representatives (i.e., congresspeople), but some states also have elections for a lieutenant governor, secretary of state, attorney general, etc. At the city and county levels, they have elections for mayors, ${ }^{\mathrm{x}}$ councilors, prosecutors, judges, etc. (Zhao Xinshu, 2003: pp.10-11) As a result, elections have become a social activity that Americans take for granted as a basic form of American democracy.

The founders of the United States designed a political system based on "Officials' Elections," that is, the people decide who will hold the power of the state through regular elections. Therefore, the people possess a binding power over those in power, and this is maintained by the mutual competition of the parties and their rule. Madison, the drafter of the U.S. Federal Constitution, declared: "I will continue to uphold this great republican principle - that the people have the virtue and the wisdom to choose those who have both the virtue and the wisdom to represent their interests." (Bernard Bailyn, 2007: pp. 314-315) Most importantly, the people's vote can effectively constrain their rulers because elected politicians will lose the support of the voters in the next election if they do not keep their campaign promises and consider the interests of the voters when making decisions. So, an electoral system guarantees indirect democracy, which means that elections are an indirect way for people to exercise national sovereignty.

Since people are made up of different groups with varying interests, politicians must have the support of diverse groups of voters. The fairness of voting, however, relies on the minority being subordinate to the majority, as this is the fundamental value of democracy. This assumes that the citizens of a country have an equal right to vote. Despite voting rights being restricted for minors and a small number of prisoners, other suffrage restrictions based on gender, race, and economic status violate democratic principles, that is, "universal suffrage."

The universality of elections is an important indicator of a country's democratic development, as universal suffrage implies that everyone is equal. However, universal suffrage does not necessarily lead to equality for all, as one person (i.e., one vote) is not always equal to another person's single vote because the "voting power" of different people may vary. One person's vote may equal two votes of another, just as one vote may equate to half of a vote for someone else. Already, this reduces the directness of an election.

\section{2) The Directness of Elections}

The electoral system can be divided into direct and indirect elections. Direct elections occur when voters elect a country's leaders or policymakers. For example, the President of France is directly elected by voters across the country. Indirect elections, on the other hand, occur when leaders are chosen by representatives who are elected by the people. The federal president of Germany, for example, is elected by the Federal Assembly, which is composed of Bundestag members. Specifically, the representatives are elected by the states according to population proportions. (Zhao 
Xiangyang, 1990: p. 497) Direct elections allow voters to choose the national leaders they trust, which may better reflect public opinion and serve to realize the will of the voters. Also, it is more effective at mobilizing citizens' enthusiasm to participate in managing state affairs.

Direct elections do not equate with direct democracy, where people vote on major state affairs to embody the unity of sovereignty and governance. Direct elections, on the other hand, simply involve the voters' selections of representatives to exercise state power. This exemplifies a distinction between sovereignty and governance, which is essentially an indirect democracy. Under an indirect democracy model, appointing people's representatives guarantees democracy; the election of representatives is also a basic form of a democratic operation. As a result, people tend to think that elections are equal to democracy, but in fact, an election is not the same but only an aspect of democracy. Direct elections through a "One Person, One Vote" process can better guarantee the expression of the people's will, but a few people still decide state affairs on behalf of the masses. However, they allow people to choose their representatives, which strengthens their sense of responsibility toward the people and contributes to protecting their rights.

\section{3) The Competitiveness of Elections}

Elections should be competitive, that is, more than two people should run for the same office, or the election loses its substance. If the public is allowed to vote on only one candidate, it deprives them of having a choice. Even though people can vote against a candidate, abstain from voting, or vote for someone else, the election would have no significance, as voting would be a mere formality. A democratic electoral system should be based on people's right to decide, which is determined by providing the offer of a genuine choice.

In these elections, the candidates may represent different parties; the intensity of competition may be high or low. Accordingly, some scholars have divided the concept of democracy into two categories, which include "high democracy" and "low democracy." (Wang Zhanyang, 2012; Ye Changmao., 2012) However, a competitive election must have multiple candidates, as a competition cannot exist otherwise. In this civilized form of a power struggle, a few politicians openly compete for power while the public watches and makes their selections. Like sports, only a few players compete on the field and most people are spectators. The players can win support from the spectators (i.e., they can have many fans or only a few), but fans can only shout from the sidelines. If fans from both sides also play a role in the contest, it will foment unrest and potentially civil war. Therefore, in a society, it is best if few people are involved in a political struggle because in a modern democratic country, it should be civilized. For the participants, the results should hinge on either winning or losing rather than a winner-take-all scenario where one's life is on the line.

In summary, a direct election with universal suffrage is the best system for guaranteeing indirect democracy, and it has been the most frequently adopted process by current democratic countries across the world. Voting is the most visible form of democracy, and it is easily recognized and supported by the public. The social costs of this "visible democracy," however, are high. For example, the 2019 Indian general election cost as high as 5 billion USD from April 11 to May 20. (Li Tianyu, 2019) The Western multi-party competitive election system may also lead to frequent governmental changes, which affects efficiency and policy continuity. So, although an electoral democracy is valuable, it also has its disadvantages since every system has both merits and demerits.

\subsection{Drawing Lots can Substitute Democratic Elections}

In the ancient Athenian city-state, people directly exercised their power through the Ecclesia, the permanent Ecclesia Council, and the People's Court. The Ecclesia was responsible for deciding the administrative affairs of the city-state, while the latter bodies heard a variety of cases. Some thought the court was the most important authority, as hearing cases was considered to be the most important public affair during this period. The members of the Council and the People's Court were elected by drawing lots among qualified citizens. Specifically, the public officials of Athens, including nine consuls that corresponded to the chief executive, were selected by drawing lots, (Wang Shaoguang, 2018: pp. 15-21)and this was the principal method for Athenian citizens to elect their representatives and officials.

With the expansion of the country's geographical area and an increasing population, the political practice of drawing lots gradually diminished. Regarding the changes that occurred in Western democracy after the $19^{\text {th }}$ century, Professor Wang Shaoguang says:

What is the most important is that the internal relationship between democracy and drawing lots, which lasted for more than two thousand years, has been spun off and cut off. Drawing lots has gradually faded out. Instead, elections, once seen by thinkers through the ages as the hallmark of oligarchy, became the hallmark of democracy. To fight for democracy meant to fight for the right to universal suffrage. Elections became all about picking a bunch of elites to govern the state. Democracy no longer meant civilians - the majority of the population being directly in charge of themselves - but that the people were surrendering their power of governance to a small group of elites with more votes. The essence of democracy was evacuated and put on a fancy coat. After 
perpetrating the fraud, 'Democracy' has become 'Electacy'. (Wang Shaoguang, 2018: p. XIX)

Some modern thinkers have also affirmed the relationship between drawing lots and democracy, although they did not wholly appreciate this democratic style. Montesquieu, for example, said, "It is in line with the nature of democratic politics to select officials by drawing lots, and it is in line with the nature of aristocratic politics to select officials by election." However, Rousseau believed:

In a true democracy, it is not inconvenient to draw lots, as it is a place where all men are equal, in morality and ability, as well as in virtue and wealth, so that it hardly matters whom you select.

Therefore, the ballot is appropriate for "places where special talents are required, such as military posts [...] while drawing lots is appropriate for places only requiring sound sense, impartiality, and probity, such as the judicial office." (Wang Shaoguang, 2018: pp. 378-379)

In the late $20^{\text {th }}$ century, the disadvantages of the democratic model, which consists of a multi-party competition and popular vote as its basic elements, has gradually emerged. Some Western scholars have begun to reflect and explore other ways of realizing democracy, like Professor Robert Dahl, former President of the American Political Science Association. In his book, Democracy and Its Critics, which was published in 1989, he suggested drawing lots to establish a "micro-crowd" consultative democracy. Later, some of Professor Dahl's students continued to discuss the democratic value of drawing lots and even formed, the "Yale School of Democratic Reform," which was characterized by its promotion of this concept. (Wang Shaoguang, 2018: pp. 419-436)

Compared to voting, drawing lots is obviously not a rational choice, and it may not be able to achieve the goal of appointing sages. However, it may compensate for some of the drawbacks that occur from the voting process. First, it reduces the electoral machinations and prevents strongmen from manipulating an election's results. Second, it can curb the vicious fighting between parties that commonly occurs in voting systems, maintaining both a smooth election process and social harmony. Third, it can ensure the equal participation of citizens as well as fair and equal elections that have more results. In a nutshell, the process of voting or selection through drawing lots both have advantages and disadvantages, but a combination is likely the best way to guarantee indirect democracy's success.

At the beginning of the $21^{\text {st }}$ century, some European and American countries began to experiment with drawing lots by generally applying it to the selection and appointment of nonprofessional posts, such as the formation of assemblies concerning major national issues. In 2004, the Canadian province of British Columbia held an assembly on electoral reform with randomly selected representatives, who were chosen by various provincial constituencies. In 2006, Ségolène Royal, a French Presidential candidate, promised to form the "Council of Burghers" to discuss constitutional changes with an elected national assembly. In 2007, the Netherlands adopted Canada's model for its national electoral reform, which entailed 142 representatives that submitted their proposals by lots. In 2010, Iceland bypassed political parties to amend its Constitution, and 950 citizen representatives were randomly chosen by computers to form a "State Forum," where they discussed and submitted recommendations. (Wang Shaoguang, 2018: pp. 442-444) In modern countries, elections that are completed by drawing lots can serve as institutional guarantees for indirect democracy's success.

\subsection{Approach to Improve China's Democratic Electoral System}

\section{1) The Unsuitability of Multi-party Elections}

During the Yan'an period, the CPC announced the slogan, "democratic politics, election first." At the time, people in the border areas had adopted the practice of "throwing beans" to realize their democratic right of being masters of their country. (Zhuo Zeyuan, 2018: p. 110) China's current democratic election system primarily consists of two parts, which are the election of deputies to the People's Congresses, as well as electing government heads and principal officials at all levels. According to the Electoral Law's relevant provisions, deputies to the People's Congresses at the county and township levels are directly elected by the voters, while those at lower levels are indirectly chosen by elected representatives. Specifically, deputies for the Municipal People's Congresses are elected by county-level delegates, while deputies to the Provincial Congresses are elected by municipal-level delegates and the NPC members are elected by provincial-level delegates. ${ }^{\text {xi }}$ Similarly, major officials at all levels are indirectly elected by deputies, so the President and Vice President of the Republic are elected by NPC deputies, while provincial governors and mayors are elected by deputies from congresses at the same level. As the ruling party, the CPC is responsible for administrating elections at all of these levels, including policy guidance, candidate recommendations, and formulating election rules.

The CPC leadership is the basic feature of China's political system, which is clearly stipulated in the Constitution of the Republic as a prerequisite for China's democratic system. Therefore, no two-party or multi-party elections can currently exist in China. Although it is unsuitable for citizens to directly vote for their national leaders and NPC deputies, China's democratic election system needs constant improvement under the CPC leadership. 
After absorbing the experiences and lessons of the Cultural Revolution, China announced reforms to its democratic electoral system and implemented some breakthroughs. For example, after the promulgation of the new Electoral Law in 1979, there were "campaigns" to directly elect deputies to the county-level People's Congresses. ${ }^{\text {xii }}$ In 1998 , the passing of the "Organization Law of Village Committees" commenced the practice of selecting the heads of village committees via "auditions." On this basis, Sichuan and other places have experimented with direct elections of their township heads. The Organization Law of Village Committees was revised in 2010 and followed by the "Regulations for the Election of Village Committees" three years later. This served to further clarify the procedures for the village committee elections. By December 2015, over 98\% of the villages in eight provinces (i.e., autonomous regions and municipalities directly under the central government) had conducted direct elections, and the average participation rate was over $95 \%$. Of course, these "auditions" had some issues, like vote-buying and clan forces interfering. (Yu Keping, 2018: pp.91-95)

Obviously, China's current democratic electoral system continues to have some shortcomings. According to a previous analysis of the voting system, China's electoral system is fairly universal, ${ }^{\text {xiii }}$ but it lacks directness and competitiveness. As mentioned above, the NPC deputies are elected by the provincial deputies, who are elected by the municipal deputies, who are elected by the county or district deputies, who are directly elected by the people. After these three levels of "progressive" indirect elections, the "representative relationships" between deputies of the NPC and the people disappear.

The competitiveness of Chinese elections is another shortcoming since only one candidate is elected for each office or governmental post by the people's congresses. The national leaders are elected through "non-competitive elections" by NPC deputies, and the leaders of local governments are elected through "non-competitive elections" by deputies of the people's congress at the same level. Therefore, to ensure that the people are the true masters of the country, China must promote the directness of elections in order to enhance their competitiveness.

2) Drawing Lots: The Indirect Election of Deputies to the People's Congresses

Since the 1980s, China's leaders have been discussing the issue of directly electing deputies to the people's congresses, starting at or above the city-level. At the time, they concluded that it did not align with China's national conditions. In 1987, Mr. Deng Xiaoping said:

In such a big country as ours, with such a large population, imbalance among different regions and so many ethnic groups, the conditions are not ripe for direct elections of top leaders, because, first of all, the candidates lack cultural quality. (Deng Xiaoping, 1993: p. 242)

Mr. Peng Zhen, on the other hand, believed that "the county level is the grassroots. With more than 2,000 counties in China, deputies should be directly elected by the people." By electing deputies to the people's congresses at higher levels, the "900 million people will take the future of the country into their own hands." (Peng Zhen, 1991: pp. 384-385) According to this mode of indirect election, the key to ensuring that people are the masters of the country is to maintain the connection between voting at the grassroots level and electing deputies at the higher levels. Although deputies to the congresses hold competitive elections, ${ }^{\text {xiv }}$ all of the candidates are already selected in advance. Thus, for indirect elections, the selection of candidates is the solution to guaranteeing a connection between the higher level deputies and the voters at the grassroots level.

Amended in 2015, Article 29 of the Electoral Law stipulates:

Candidates for deputies to the national and local People's Congresses at various levels shall be nominated by electoral districts or units. All political parties and people's organizations may jointly or independently recommend candidates for deputies. Voters or deputies with more than 10 signatures may also recommend candidates.

Among the aforementioned nomination methods, recommendations by political parties and other organizations remains the primary approach, where the candidate that is recommended by the CPC carries the most weight. In fact, the organizational department of the party committee plays the most crucial role in selecting candidates for deputies to the people's congresses. In some areas, the selection is "internally determined" by a small number of leaders. Professor Wang Shaoguang says:

The so-called party and group nominations often only reflect the likes and dislikes of their leaders. In order to get people they trust and want to be elected, some party committees or groups, will, in most cases, recommend candidates at their own discretion. They rarely advertise the candidates or solicit the general public's opinions. (Wang Shaoguang, 2018: p. 32)

These kinds of black-box nominations can not only lead to malpractice and favoritism but also to the buying and selling of public offices. In recent years, the anti-corruption struggle in China has revealed serious official corruption, and one of the main reasons for this is the excessive concentration of leadership power. In some localities, or units, the 
leaders are domineering and overbearing. They deceive the public, follow their personal interests, engage in cronyism, and have the final say when it comes to the selection and appointment of cadres, including deputies to the people's congresses. As a result, "Relation" has become the hidden rule of officialdom, which includes entertaining and gift-giving as well as the buying and selling of public offices. When prestigious official positions, including NPC deputies and CPPCC members, become "commodities" that can be bought and sold, official corruption becomes increasingly rampant. This is a common situation in the corruption cases of senior officials. (He Jiahong \& Xu Yuedi, 2016: pp. 4-10)

Deputies at the county-level of the people's congresses are directly elected by the people. So, if deputies to the people's congresses at the next higher level were elected and appointed by the county-level deputies, then a certain link could be drawn between them and the people. This would maintain public oversight and create a binding force among the deputies. Article 32 of the Electoral Law stipulates, "when a local people's congress, at or above the county level, elects deputies to the next level congress, candidates are not limited to be deputies at that level." Although this regulation implies that candidates should primarily be deputies to the people's congresses at their respective levels, it also makes it easier for leaders at all levels to recommend their favorites. As a result, many who had no connection to the local voters are listed as candidates through "Relations" or "Labeling." Meanwhile, the number of NPC deputies who are directly elected by the people is relatively small.

This author utilized a method that involved big data to calculate the number of county-level deputies at the $13^{\text {th }}$ NPC. Due to incomplete information disclosures concerning the provincial and autonomous regions of the people's congress websites, only some municipalities directly under the central government, like Bejing and Shanghai, display relatively complete information. In 2019, among the NPC deputies, there are fifty-five deputies from the Beijing Delegation, which include only three $(5.45 \%)$ from the district-level people's congresses, and there are fifty-seven deputies from the Shanghai Delegation, which include five (9\%) from the district-level people's congresses. In other words, less than ten per cent of the NPC deputies are direcly elected by the people.

In the same year, there are 759 deputies in Beijing's Municipal People's Congress. Of these, 271 (38\%) are also deputies of the district-level people's congresses (excluding the Fangshan District, as its list of deputies is not available). There is a total of 855 deputies in Shanghai's Municipal People's Congress. Of these, 156 (19\%) are also district-level deputies (excluding Jiading District, as its list of deputies is not available). ${ }^{\mathrm{xv}}$ Although these figures are not precisely accurate, they provide a glimpse into the issues at hand.

To protect the people's right to be masters of their country, we must strengthen the relationship between NPC deputies and their constituents. Also, we must improve our electoral system. The author believes that it is feasible to introduce a random drawing mechanism when determining candidates for indirect election. Specifically, this refers to NPC deputies as well as deputies to the people's congresses of the provinces, autonomous regions, and municipalities under the central government. For example, the deputies of the Municipal People's Congress will be primarily chosen among the deputies at lower level. When determining the list of candidates, the People's Congress at the lower level will draw lots with $90 \%$ of their candidates ${ }^{\mathrm{xi}}$ from the deputies of the People's Congress. If the district is entitled to send twenty deputies to the Municipal People's Congress, but the number of candidates can reach thirty. Of these, twenty-seven will be drawn by lots from the deputies of the District People's Congress, while three will be selected by political parties or organizations through consultations. On this basis, the municipality deserves sixty NPC deputies, while the number of candidates can reach ninety. Thus, eighty-one of the candidates should be drawn by lots from the deputies of the Municipal People's Congress, while the remaining nine candidates will be selected by political parties or organizations through consultations.

Drawing lots to select candidates for deputies of the people's congresses will not affect the quality and reliability of the elected deputies. First, deputies to the people's congresses at the district and county levels have all passed qualification examinations and elections at the grassroots level. Second, unlike the primary government leaders, NPC deputies are not professionals and can be selected by drawing lots. Third, these candidates must be elected by the People's Congress at the same level to become deputies at a higher level. Most importantly, the practice of "drawing first and voting later" can strengthen the link between the higher-level deputies and voters at the grassroots level, which could boost the people's representation among the NPC deputies. In other words, those who intend to run for an NPC deputy position should begin at a county-level election rather than simply taking the "upper-level line" to win the leader's favor. To provide greater lower-level deputies more opportunities to advance, the law may also stipulate that deputies drawn by lots are not allowed to serve a second term.

\section{3) Competitive Local Government Elections}

To reiterate, democratic elections should be competitive, or they will pass by in vain. In China's current political system, competitive elections should first be applied to the local government's major leaders. ${ }^{\text {xvii }}$ In the 1980s, China introduced 
competitive elections for local government heads. The Local People's Congress and the Local People's Government Organization Law (the "Local Organization Law") promulgated in 1979 and was amended in 1982. It stipulates that a "competitive election" is a key principle for the elections of local state leaders. In 1986, the heads of the NPC's Standing Committees in twelve provinces, the governors of eight provinces, the court presidents of fifteen provinces, and the procurators of eleven provinces conducted competitive elections at the county and township levels. Perhaps due to conditions in the competitive elections that are beyond control, the Local Organization Law was amended again at the end of 1986, and the principle of competitive elections was changed into one of "ambiguity." "xviii As a result, competitive elections for local government heads significantly decreased in the early 1990s. There were also "democratic accidents" in some provincial elections, including candidates who were nominated by the presidium of the NPC and defeated while the "co-electors" won (e.g., the governor elections in Zhejiang and Guizhou). ${ }^{\text {xix }}$ Also, in the election of municipal and county government leaders in some local areas, candidates that were determined by superior organizations were also defeated. (Wang Shaoguang, 2014: p. 37-39) Perhaps due to these mishaps, the idea of competitive elections for the local heads of government have existed in name only.

Professor Wang Shaoguang explains:

In the past few years, all the official posts of the state organs from the provincial to the township levels were elected through non-competitive elections, and the only candidates were almost all arranged by the organizational departments of the Party committee. As for the election of deputy officials, since the Local Organization Law clearly stipulates the implementation of competitive elections (1-3 more candidates), party committees and departments in various regions have adopted the strategy of the lowest number of candidates (i.e. only one more competitive candidate). In order to ensure the success of this strategy, some local party committees have tried every means to prevent deputies to the People's Congress from jointly nominating candidates or arranging for reliable people to act as 'co-electors.' As a result, the election of principal and deputy officials has become a formality; the role of the NPC deputies is nothing more than to raise their hands and draw circles, completely defiling the meaning of the election. (Wang Shaoguang, 2014: p. 37)

The CPC is the only ruling party in China, ${ }^{\mathrm{xx}}$ and it is natural that the ruling party should nominate the candidates for governmental leadership. However, as far as elections are concerned, selecting only one candidate is a sham. Therefore, one of the ways to perfect the democratic election system is to carry out a competitive election of governmental heads, which may begin with local governments and the election of principal officials. It is no secret that some local leaders have become accustomed to the practice of selecting candidates through consultation and noncompetitive elections, so they lack the enthusiasm to carry out competitive elections. The author suggests that the NPC's Standing Committee amend the Local Organization Law again to delete the provision in Article 22 that states, "a noncompetitive election may also be conducted." If the NPC's Standing Committee is unable to amend the law in the near future, it will be necessary to utilize legislative interpretation to clarify that the election of people's government leaders will be based on the principle of competitive election, except for certain noncompetitive elections where a review mechanism will be established. Although competitive elections may have "nominal co-electors," the existence of these marks significant progress toward establishing a democracy within China's electoral system.

\section{Conclusion}

In summary, the practical pathway toward democracy in current China is to take substantial measures to guarantee people's democratic rights, including the right to know, the right to speak, and the right to vote. According to the experiences in many countries in the world, the development of democracy should go with the rule of law. Therefore, China should speed up the progress for the rule of law.

"Ruling the country by law and building a socialist country under the rule of law" was proposed as a general strategy for governing the country at the CPC's $15^{\text {th }}$ National Congress in 1997, and for the first time, the wording, "Legal System" has been replaced by the "Rule of Law." In 2002, at the $16^{\text {th }}$ National Congress, the CPC further elaborated on these requirements and specified the targets for building a country under the rule of law, and a new leadership transition was completed, which was based on the Constitution. In 2007, at the $17^{\text {th }}$ National Congress, the CPC ordered a faster construction of a socialist country under the rule of law. In 2012, the CPC decided to comprehensively promote the rule of law at its $18^{\text {th }}$ National Congress. In 2014 at the $4^{\text {th }}$ Plenary Session of the $18^{\text {th }}$ CPC Central Committee, a strategic plan was adopted called, Decision of the CPC Central Committee on Major Issues Pertaining to Comprehensively Promoting the Rule of Law. This clarified that the CPC's overall goal is to promote the rule of law by creating a socialist legal system with Chinese characteristics and building a socialist country under this rule of law. (Zhuo Zeyuan, 2018: pp. 108, 116, 143, 156)

However, the most important way to measure the level of a country's rule of law is not through legislation or the completeness of available laws but enforcement and the implementation of the law. Without the law, a rule of law is, of 
course, impossible, but with the law, the rule of law still does not necessarily function appropriately. The fundamental problem facing China is not a lack of laws but that they do not operate well. In other words, the effort toward promoting the rule of law should refocus on enforcement rather than legislation. A key objective of the rule of law is to govern officials and rein in their power. Democracy should be progressively developing in China, and it should be predicated on the rule of law because without it as the cornerstone, democracy remains like a castle in the air.

\section{Conflicts of Interest}

The author declares no conflicts of interest regarding the publication of this paper.

\section{About the author}

He Jiahong, SJD, Northwestern University, USA (1993); Grand China Chair Professor, Director of the Center for Anti-Corruption and Rule of Law, Director of the Center for Common Law, Director of the Center for Wrongful Conviction Study, and Director of the Institute of Evidence, Renmin University of China; Vice President of China's Society of Law and Behavior Science, Specially Invited Adviser of the Supreme People's Court, Expert Adviser of the Supreme People's Procuratorate, Member of the Ethics Committee, Federation International of Football Association (FIFA, 2017-). Prof. He has published dozens of law books and five crime novels in Chinese. His law book, Back from the Dead: Wrongful Convictions and Criminal Justice in China, has been published in English, French, German, Hebrew, Spanish, and Portuguese. His crime novels have been published in French, Italian, Spanish, and English. His new book on evidence law, Methodology of Judicial Proof and Presumption, was publisehd in English by Springer in March 2018. See Tom Mitchell: Lunch with the FT: He Jiahong, Financial Times, 21 February 2015.

\section{References}

Bernard, B. (2007). The Ideological Origins of the American Revolution (Translated by Tu Yongqian). the Press of China University of Politics and Law.

Deng, X. P. (1993). Selected Works of Deng Xiaoping (Volume III). People's Publishing House.

He, J. H., \& Xu, Y. D. (2016). The Causes and Blocks of the Corruption Interest Chain: An Empirical Analysis of the Corruption Cases of the Sacked Officials after the 18th National Congress. Political and Legal Forum, 34(3).

Li, T. Y. (2019). The launch of the most powerful election in the world - how India lets illiterate people vote", Sohu News. Retrieved from http://www.sohu.com/a/309199742_115479?spm=smpc.home.top-news3.6.1555733533007TnBTXyT\&_f=index_ news_11.2019.05.20

Mo, Y. C. (2015). On Essentials of Democratic Administrative Law.

Peng, Z. (1991). Selected Works of Peng Zhen. People's Publishing House.

Pi, C. X. (1986). The Concise Political Science Dictionary. Henan People's Publishing House.

Wang, Z. Y. (2012). China Urgently Needs to Develop Low Democracy. Exploration and Free Views, 2012(1).

Yang, N. Q. (2013). Life in which dynasty is the most frustrating. Guangxi Normal University Press.

Ye, C. M. (2012). The Essence of Low Democracy Should be Low Competition - and Discussion with Mr. Wang Zhanyang. Exploration and Free Views, 2012(8).

Yu, K. P. (2018). How is China governed? The Road to Modernization of State Governance. Foreign Languages Press.

Zhang, G. H. (1982). The History of Chinese Legal Thoughts. Law Press.

Zhang, J. F. (1985). The History of Law in China. Qunzhong Press.

Zhao, X. S. (2003). The Dilemma of Election: Critique of the Democratic System and Constitutional Reform. Sichuan People's Publishing House.

Zhao, X. Y. (1990). An Overview of the Political System of Contemporary Capitalist Countries. Henan People's Publishing House.

Zhuo, Z. Y. (2018). Rule of Law in China. Foreign Language Press.

\section{Notes}

${ }^{\mathrm{i}}$ In September 2017, this author was invited to the $5^{\text {th }}$ Athens Democracy Forum, which was cofounded by The New York Times, the United Nations Foundation for Democracy, and the Athens City Council. As a keynote speaker in the session, "Rethinking Democracy in the Changing World," on 15 September (International Democracy Day), the author 
shared his perspectives concerning China's trend toward democracy, including early developments, lessons from the Cultural Revolution, the present situation, and the issues with democracy in China. He said that China should learn from other countries, and although democracy can be imported, it cannot be exported. Some participants at the Athens Democracy Forum agreed with his perspective. On 22 September 2017, a week later from the Forum, this author received an email from Mr. Achilles Tsaltas, Vice President of International Conferences, The New York Times. He wrote, "Same time last week you made your valuable remarks in Athens and now you are quoted online and please see our special report that covers the conference and its themes (see attached World Review). I agree with you saying that democracy cannot be exported but it can be imported.Thank you so much for being part of Athens Democracy Forum and enriching the experience of our audience. We hope you found it as valuable as we did."

ii Ancient Chinese writings contained no punctuations. So this saying by Confucius was interpreted differently by scholars of later generations. It may have different or even totally opposite meanings when punctuated differently. The translation herein is based on a punctuated version that might have misunderstood the original intention of Confucius but is widely accepted. Here the author has no intention to dig into the original meaning of Confucius, as how it is used by the people is of more realistic significance.

iii The Constitution of The People's Republic of China, Law Press, 2012, pp.95-101.

iv The Constitution of The People's Republic of China, Law Press, 2012, P.90.

v The Constitution of The People's Republic of China, Law Press, 2012, P.93.

${ }^{\mathrm{vi}}$ This is a new concept put forward by some western scholars in recent years. In addition to electronic democracy, there are also computer democracy, teledemocracy, cyber-democracy, digital democracy, and virtual democracy.

vii The so-called "selection" means the bestowal of office according to capacity.

viii See Etymology (Revised), The Commercial Press, 1988, p. 1680.

${ }^{\text {ix }}$ See Ocean of Words - Words Volume (Revised, Volume I), Shanghai Lexicographical Publishing House, 1979 edition, p. 1108 .

"Counties in the United States do not have "Heads of the County," but they do have elected sheriffs, who are responsible for police and prison management.

${ }^{x i}$ Article 2 of the Electoral Law stipulates: "Deputies to the National People's Congress and to the People's Congresses of provinces, autonomous regions, municipalities directly under the central government, cities divided into districts, and autonomous prefectures shall be elected by the people's congresses at the next lower level. Deputies to the People's Congresses of cities not divided into districts, municipal districts, counties, autonomous counties, townships, nationality townships and towns shall be elected directly by their constituencies."

xii In 1981, when the district and county People's Congress deputies in Beijing were elected, I was still a university student and witnessed the scene of student candidates who competed with the principal for the deputies to the NPC entering into the classroom for "election."

xiii Article 3 of the Electoral Law stipulates: "All citizens of the People's Republic of China who have reached the age of 18 have the right to vote and the right to stand for election, regardless of nationality, race, sex, occupation, family background, religious belief, education, property status or length of residence. Persons deprived of their political rights by law have no right to vote or right to stand for election."

xiv Article 30 of the Electoral Law stipulates: "Deputies to the national and local people's congresses at various levels shall be elected through competitive elections, and the number of candidates for deputies shall exceed the number of deputies to be elected."

${ }^{\mathrm{xv}}$ Description of statistical methods: (1) information collision method is adopted in the statistics of the number of deputies to the National People's Congress and the district and county People's Congresses while at the same time in the Beijing and Shanghai Delegations. In other words, the information is obtained through the collision of the information searched from news on the Internet and photos released by the National People's Congress and other sources, with relatively high accuracy. (2) when calculating the number of deputies to municipal People's Congresses and to district and county People's Congresses at the same time in Beijing and Shanghai, the list comparison method is adopted. In other words, the information is obtained by comparing the names, genders, nationalities and other information in the list of deputies published by the standing committees of People's Congresses at all levels. Since the situation of the same name, gender, and nationality cannot be excluded, and the deputy lists of some districts is not known, the statistical results are not accurate enough. Thanks to Lü Hongqing, a doctoral candidate of Renmin University of China Law School, for his contribution to the statistics. 
${ }^{x v i}$ Article 30 of the Electoral Law stipulates, "Where a local People's Congress at or above the county level elects deputies to the People's Congress at the next higher level, the number of candidates for deputies shall exceed the number of deputies to be elected by one-fifth to one-half."

xvii According to the provisions of Article 8 of the Local Organization Law, the main leaders of local governments elected by the People's Congresses at or above the county level include: governor, deputy governor, chairman and vice-chairman of the autonomous region, mayor, deputy mayor, nomarch, deputy nomarch, county magistrate, deputy magistrate, district head, deputy district head, president of the people's court, and procurator-general at the same level.

xviii According to the provisions of Article 22 of the Local Organization Law, as amended in 1986, the number of candidates for the principal leaders of the People's Government, the president of the People's Court, and the chief procurator of the People's Procuratorate should generally be one more for competitive elections. If there is only one nominated candidate, a non-competitive election may be conducted. The number of candidates for deputy leaders of the people's government should be one to three more than the number of candidates to be elected in order to hold a competitive election.

xix On January 15, 1993, at the 1st Session of the 8th National People's Congress of Zhejiang Province, Ge, the candidate who was "internally determined" to be governor of Zhejiang, was defeated, Wan, the "co-elector," was chosen to be governor, and Ge was later made deputy director of the Office of the State Council. On the same day, in the provincial governor election of Guizhou Provincial People's Congress, the "internally determined" candidate Wang was defeated, Vice Governor Chen was elected governor, and Wang was later elected Chairman of the Ethnic Affairs Committee of the National People's Congress.

${ }^{x x}$ As the ruling party, the democratic electoral system within the communist party is closely related to the national democratic electoral system. In the mid-1980s, the Central Committee of the Communist Party of China decided to implement competitive elections for party committee members in order to strengthen intra-party democracy. At the 13th National Congress of the Communist Party of China held in October 1987, members of the CPC Central Committee were elected for the first time through competitive election. Deng Liqun, the then Secretary of the Secretariat of the CPC Central Committee and Head of the Publicity Department of the CPC Central Committee, was defeated in the election and was later elected to the Advisory Committee of the CPC Central Committee. This practice has been going on for 30 years. In October 2017, the primary elections for members and alternate members of the 19th National Congress of the Communist Party of China and members of the Central Commission for Discipline Inspection were also adopting competitive elections, with $8 \%$ more candidates added.

\section{Copyrights}

Copyright for this article is retained by the author(s), with first publication rights granted to the journal.

This is an open-access article distributed under the terms and conditions of the Creative Commons Attribution license which permits unrestricted use, distribution, and reproduction in any medium, provided the original work is properly cited. 